\title{
Pulmonary function and factors associated with current smoking among the hill tribe populations in northern Thailand: a cross- sectional study
}

Anongnad Mee-inta ${ }^{1 *}$, Ratipark Tamornpark ${ }^{2,3}$, Fartima Yeemard ${ }^{3}$, Panupong Upala ${ }^{3}$ and Tawatchai Apidechkul ${ }^{2,3^{*}}$

\begin{abstract}
Background: Smoking is considered one of the major poor health behaviors leading to several health problems. Individuals with a poor education and economic status are vulnerable to smoking, particularly the hill tribe people in Thailand. This study aimed to estimate the prevalence of current smoking, assess pulmonary function, and identify factors associated with current smoking among individuals aged 20 years and older of the hill tribes in northern Thailand.

Method: A cross-sectional study was conducted to gather information from the hill tribe people living in 42 hill tribe villages. A validated questionnaire, spirometry, and pulse oximetry were used as the research tools. Face-to-face interviews were conducted to collect data from the participants in a private room after obtaining informed consent voluntarily. Chi-squared test and logistic regression were used to detect the associations between the variables at the significance level of $a=0.05$.

Results: In total, 2216 participants were recruited into the study: 54.6\% were women, 80.3\% were aged 31-59 years, and $86.1 \%$ were married. The prevalence of smoking was $36.3 \% ; 20.6 \%$ were current smokers (36.7\% among men and $7.0 \%$ among women), and $15.7 \%$ were ever smokers. Half of the participants (50.1\%) had smoked for $\leq 9$ years, $80.1 \%$ smoked $\leq 10$ pieces per day, $64.2 \%$ smoked traditional tobacco, $42.8 \%$ had low-to-moderate levels of knowledge of the harms of smoking, and $68.4 \%$ had low-to-moderate levels of attitudes toward the harms of smoking. Only sex was statistically significant among the different smoking behaviors ( $p$-value $<0.001$ ), and the participants' pulmonary function was not significantly different. After controlling for age, sex, religion, and education, three variables were found to be associated with current smoking among the hill tribe people in Thailand: men were more likely to smoke than women ( $\mathrm{AOR}=7.52,95 \% \mathrm{Cl}=5.53-10.24)$; those who used amphetamines were more likely to smoke than those who did not (AOR $=2.92,95 \% \mathrm{Cl}=1.69-5.03)$; those who had poor attitudes toward the harms of smoking were more likely to smoke than those who had a positive attitude toward the harms of smoking ( $\mathrm{AOR}=2.47,95 \% \mathrm{Cl}=1.53-3.97$ ). (Continued on next page)
\end{abstract}

\footnotetext{
* Correspondence: anongnad.mee@mfu.ac.th; Tawatchai.api@mfu.ac.th

'Department of Physical Therapy, School of Integrative Medicine, Mae Fah Luang University, Chiang Rai, Thailand

${ }^{2}$ Department of Public Health, School of Health Science, Mae Fah Luang University, Chiang Rai, Thailand

Full list of author information is available at the end of the article
}

(c) The Author(s). 2020 Open Access This article is licensed under a Creative Commons Attribution 4.0 International License, which permits use, sharing, adaptation, distribution and reproduction in any medium or format, as long as you give appropriate credit to the original author(s) and the source, provide a link to the Creative Commons licence, and indicate if changes were made. The images or other third party material in this article are included in the article's Creative Commons licence, unless indicated otherwise in a credit line to the material. If material is not included in the article's Creative Commons licence and your intended use is not permitted by statutory regulation or exceeds the permitted use, you will need to obtain permission directly from the copyright holder. To view a copy of this licence, visit http://creativecommons.org/licenses/by/4.0/ The Creative Commons Public Domain Dedication waiver (http://creativecommons.org/publicdomain/zero/1.0/) applies to the data made available in this article, unless otherwise stated in a credit line to the data. 
(Continued from previous page)

Conclusion: Translating essential health messages into the hill tribe language and improving the channel to deliver this information to the target populations, particularly men, are crucial strategies for improving their knowledge and attitudes toward the harms of smoking and making them quit smoking.

Keywords: Pulmonary function, Hill tribe, Smoking behaviors, Factors associated

\section{Background}

Smoking is an important health behavior that may lead to several health complications, such as cancer (CA) [1, 2], cardiovascular disease (CVD) [3], and chronic obstructive pulmonary disease (COPD) [4]. The diseases that develop from smoking behavior require costly care and treatment [5]. Most smokers end their lives with poor physical and mental health [6]. The impacts are not limited to individuals who smoke; they extend to their family members, community and nation through socioeconomic systems [6]. The World Health Organization (WHO) estimates that 1.4 trillion dollars are lost due to smoking among the global population [7]. The WHO reported that more than 8 million people are killed by smoking behavior each year; $87.5 \%$ are directly killed by smoking, and the others are killed by second-hand smoking [6]. A significant point is that more than $80.0 \%$ of those who die because of smoking live in developing countries, including Thailand.

Thailand is classified as a developing country [8] with an estimated total population of 67 million in 2019 [9]. The Thai Health Promotion Foundation reported that 553,611 patients were treated for issues related to smoking in 2017, with an expenditure of approximately 21,389 million baht [10]. The Ministry of Public Health Thailand estimated that, in the Thai population aged 15 years and older, 10.7 million people (19.1\% prevalence) were defined as smokers in 2019, and those aged 25-44 years constituted the greatest proportion of smokers [11]. In 2018, WHO reported 114,199 deaths from cancers, and 170,495 cases of cancers were treated in Thailand [12]. Among the ontreatment cancer patients, most had lung cancer (14.1\%), liver cancer (13.7\%), and breast cancer (11.4\%) [12]. Importantly, among smokers, the reduction in pulmonary function is an urgent issue, particularly among those working in agricultural sections who require extensive physical energy to complete their daily duties. A comparative study conducted in Thailand clearly indicated that those who smoked had a significantly reduced pulmonary function compared with those who did not [13]. The Ministry of Public Health stated that the populations most vulnerable to smoking have a poor education and economic status, such as the hill tribe people [14].

The hill tribe migrated from southern China over centuries to settle in the mountainous areas of northern Thailand, far from large cities [15]. The WHO reported that six main groups of hill tribes exist in Thailand-
Akha, Lahu, Hmong, Yao, Karen, and Lisu-comprising approximately 3.5-4.0 million people in 2017 [16]. All hill tribe people have their lifestyles and patterns of culture, with some patterns related to substance use behaviors, including smoking [17]. Given their living conditions, particularly poor economic conditions and poor education, the hill tribe people are highly likely to adopt smoking behaviors. Apidechkul et al. [18] reported that more than $30.0 \%$ of hill tribe people were not granted the Thai identification card (ID), which is used to access public services, including free medical services [19]. Therefore, for people who have health problems, access to medical services is difficult.

There is very limited scientific information on smoking behaviors and pulmonary function. This study aimed to estimate the prevalence of smoking, assess pulmonary function, and identify the factors associated with current smoking behavior among people of the hill tribe aged 20 years and older in northern Thailand.

\section{Methods}

Study design

A cross-sectional study design was used to gather information from the participants.

\section{Study population}

The study population was the hill tribe people aged 20 years and older. The targeted hill tribe population in the study was one of the six main tribes: Akah, Lahu, Hmong, Yao, Karen, and Lisu. Hill tribe people living in 42 selected hill tribe villages in Chiang Rai Province, Thailand, were eligible for the study. Those who were unable to provide essential information regarding the study protocols were excluded from the study.

\section{Study sample}

The sample size was calculated based on the standard formula of a cross-sectional design [20], where $\mathrm{Z}_{\alpha / 2}^{2}=$ $1.96, P=0.41$ [21], $\mathrm{Q}=0.59$, and $\mathrm{e}=0.05$. Therefore, 360 participants were required from each tribe. In total, 6 tribes and 2162 participants were needed for the analysis.

\section{Research instruments and their development}

Three research instruments were used to collect data: validated questionnaires, spirometry, and pulse oximetry. A questionnaire was developed based on a review of the 
literature and information obtained from discussion with health professionals working in small health centers located in the hill tribe villages. The questionnaire was divided into five parts. In part one, 11 questions were used to collect general information about the participants, such as age, sex, education, and marital status. In part two, 15 questions were used to collect information on smoking behaviors, such as type of smoking, duration of smoking, sources of obtaining cigarettes, and money used to buy cigarettes per day. In part three, 5 questions were used to collect information on substance use, such as alcohol use behavior, amphetamine use, and opium use. In part four, ten questions were used to detect knowledge of the harms of smoking, and another ten questions were used to collect data on attitudes toward the harms of smoking. In part five, four open-ended questions were used to obtain information on pulmonary function testing with forced expiratory volume in the first second $\left(\mathrm{FEV}_{1}\right)$, the volume delivered during an expiration made as forcefully and completely as possible starting from full inspiration (FVC), the ratio of $\mathrm{FEV}_{1}$ and $\mathrm{FVC}\left(\mathrm{FEV}_{1} / \mathrm{FVC}\right)$, and $\mathrm{O}_{2}$ saturation.

The validity of the questionnaire was tested by asking three external experts who were working in the fieldone epidemiologist, one physical therapist, and one public health professional-for the item-objective congruence index (IOC). Subsequently, a pilot test was conducted at Mae Fah Luang District comprising 20 participants with similar characteristics to the study population. In the pilot test, the same sample was assessed three times to test the feasibility, ordering of the questions, and proper questions for the hill tribe. The Cronbach's alpha of the sections on knowledge and attitudes were 0.76 and 0.71 , respectively (Additional file 1, Questionnaire).

To assess pulmonary function, a standardized pulmonary function test of the American Thoracic Society (ATS) [22] was used. Normal was classified as $\mathrm{FEV}_{1} \geq$ 80.0\%, $\mathrm{FEV}_{1} / \mathrm{FVC} \geq 70.0$, and $94.0 \%-100.0 \%$ oxygen saturation.

\section{Process of data gathering}

The hill tribe villages were selected by a random method from lists of the 6 tribe villages located in Chiang Rai Province. Based on the information in 2018, 652 hill tribe villages, including 243 Akha villages, 216 Lahu villages, 63 Yao villages, 59 Hmong villages, 36 Karen villages, and 35 Lisu villages, were identified [23]. Given the different numbers of village members, 42 hill tribe villages were selected for the study: 5 Akha villages, 8 Lahu villages, 7 Hmong villages, 6 Yao villages, 8 Karen villages, and 8 Lisu villages. Access to the selected villages was granted by the district government officers. The target village headmen were contacted and asked for a list of people who met the criteria. An appointment was made five days before collecting the data. On the day of data collection, all the participants were informed of all essential information and asked to provide informed consent before starting the interview. Each interview and pulmonary function assessment lasted $30 \mathrm{~min}$.

\section{Statistical analysis}

The questionnaires were coded and double-entered into SPSS version 24 (SPSS, Chicago, IL). Descriptive statistics were used to explain the general characteristics of the participants. Continuous data are described as means and SD, while categorical data were described as percentages. Chi-squared test was used to detect the difference in proportions between variables. Logistic regression was used to detect the associations of independent variables and current smoking at the significance level of $\alpha=0.05$. In the current study, smokers were coded as "1", while nonsmokers and never smokers were coded as "0". "Enter" was used for both univariate and multivariate analyses. The pseudo $R^{2}$ of the Cox-Snell $R^{2}$ and Nagelkerke's $R^{2}$ were used to determine the fit of the model in all steps. In the final step, age and sex were controlled as confounding factors in the model before interpretation.

\section{Results}

In total, 2216 participants were recruited into the study; $54.6 \%$ were women, $80.3 \%$ were aged $30-59$ years, and $86.1 \%$ were married. The average age of the men was 49.7 years $(\mathrm{SD}=11.3)$ and that of the women was 46.8 years $(S D=10.1)$, with a statistically significant difference $(p$-value $<0.001)$. The proportions of participants by tribes were 14.8-19.0\%. More than half were Buddhist (54.8\%), uneducated (53.4\%), and had annual family income of 10,000-50,000 baht (59.6\%) (Table 1).

Regarding smoking behaviors, 36.3\% were currently smoking, $50.1 \%$ smoked for 9 years or less, $80.1 \%$ smoked 10 pieces or less per day, $64.2 \%$ used traditional tobacco, and $89.6 \%$ spent less than 50 baht per day (2\$US). Less than half $(42.8 \%)$ had low to moderate levels of knowledge of the harms of smoking, and $68.4 \%$ had low to moderate levels of attitudes toward the harms of smoking. Regarding other substances, $42.5 \%$ used alcohol, 4.5\% used amphetamines, and 4.2\% used opium (Table 2).

Comparing smoking behaviors and pulmonary function, only sex was found to be statistically significant ( $p$ value $<0.001)$. Pulmonary function was not significantly different among the different groups of smoking behaviors (Table 3).

In univariate analyses, 12 variables were associated with current smoking: sex, age, tribe, marital status, religion, education, occupation, alcohol use, amphetamine 
Table 1 General characteristics of the participants

\begin{tabular}{|c|c|c|}
\hline Characteristics & $n$ & $\%$ \\
\hline Total & 2216 & 100.0 \\
\hline \multicolumn{3}{|l|}{ Sex } \\
\hline Male & 1007 & 45.4 \\
\hline Female & 1209 & 54.6 \\
\hline \multicolumn{3}{|l|}{ Age (years) } \\
\hline $20-29$ & 41 & 1.9 \\
\hline $30-39$ & 279 & 20.7 \\
\hline $40-49$ & 717 & 32.4 \\
\hline $50-59$ & 602 & 27.2 \\
\hline$\geq 60$ & 398 & 18.0 \\
\hline \multicolumn{3}{|c|}{ Mean $=48$, S.D. $=10.8, \operatorname{Min}=25, \operatorname{Max}=78$} \\
\hline \multicolumn{3}{|l|}{ Tribe } \\
\hline Akha & 421 & 19.0 \\
\hline Lahu & 387 & 17.5 \\
\hline Hmong & 364 & 16.4 \\
\hline Yao & 346 & 15.6 \\
\hline Karen & 329 & 14.8 \\
\hline Lishu & 369 & 16.7 \\
\hline \multicolumn{3}{|l|}{ Marital status } \\
\hline Single & 126 & 5.7 \\
\hline Married & 1908 & 86.1 \\
\hline Widowed & 111 & 5.0 \\
\hline Divorce & 71 & 3.2 \\
\hline \multicolumn{3}{|l|}{ Religion } \\
\hline Buddhism & 1214 & 54.8 \\
\hline Christian & 1002 & 45.2 \\
\hline \multicolumn{3}{|l|}{ Education } \\
\hline Uneducated & 1184 & 53.4 \\
\hline Primary education & 573 & 25.9 \\
\hline Secondary education & 341 & 15.4 \\
\hline High vocational & 83 & 3.7 \\
\hline University & 35 & 1.6 \\
\hline \multicolumn{3}{|c|}{ Annual family income (Baht) } \\
\hline$\leq 10,000$ & 210 & 9.5 \\
\hline $10,001-50,000$ & 1321 & 59.6 \\
\hline $50,001-100,000$ & 466 & 21.0 \\
\hline$\geq 100,001$ & 213 & 9.9 \\
\hline \multicolumn{3}{|l|}{ Occupation } \\
\hline Unemployed & 186 & 8.4 \\
\hline Merchant & 53 & 2.4 \\
\hline Employee & 233 & 10.5 \\
\hline Agriculture & 1744 & 78.7 \\
\hline
\end{tabular}

use, opium use, marijuana use, and attitudes toward the harms of smoking.

In multivariate analysis, after controlling for age, sex, religion, and education, three variables were found to be associated with current smoking among the hill tribe people in Thailand. Men were 7.52 times more likely to smoke than women $(95 \% \mathrm{CI}=5.53-10.24)$. Those who used amphetamines were 2.92 times more likely to smoke than those who did not $(95 \% \mathrm{CI}=1.69-5.03)$, and those who had low attitudes toward the harms of smoking were 2.47 times more likely to smoke than those who had a good attitude toward the harms of smoking 2 (95\% CI $=1.53-3.97)$ (Table 4).

\section{Discussion}

In this study, the hill tribe people aged 20 years and older living in Thailand had a poor education and economic status. One-third were smokers (36.3\%) and spent a considerable amount of money buying cigarettes, even with a low family income. They used different substances but at a low rate. Pulmonary function and oxygen saturation did not differ among the nonsmokers, ever smokers, and current smokers. Differences were found among current smokers regarding sex, tribe and age group. Characteristics that served as influencing factors of current smoking were sex, amphetamine use, and attitudes toward the harms of smoking.

The Ministry of Education, Thailand reported that $96.0 \%$ of the Thai population aged $15-59$ years were educated under the Thailand educational system; $22.0 \%$ earned a university degree, $20.0 \%$ graduated at high school level, $19.0 \%$ graduated at the secondary school level, and $35.0 \%$ graduated at the primary school level [24]. However, among the hill tribe people, 53.4\% never attended any educational system in Thailand. Concerning family income, the National Statistical Office, Thailand reported that the average annual family income of the Thai population was 323,352 baht (10,778US\$) while it was 42,000 baht (1400US\$) among the hill tribe family per year [25]. The information could reflect that the hill tribe people in Thailand have lower education and income levels than the Thai general population.

Our study found that the prevalence of current smoking among hill tribe people aged 20 years and older was $20.5 \%$, and men $(36.7 \%)$ constituted a greater proportion of smokers than women (7.0\%). However, no differences were found in the capacities $\left(\mathrm{FEV}_{1}, \mathrm{FVC}, \mathrm{FEV}_{1} / \mathrm{FEC}\right)$ and oxygen saturation of the pulmonary system among ever smokers, current smokers, and nonsmokers. The prevalence was similar to that in a nationwide study in Poland in 2019 of 1011 participants aged 15 years and older [26], at $21.0 \%$. The prevalence among European students was $66.1 \%$, and the mean age at the initiation of smoking was 16 years [27]. Studies from different countries 
Table 2 Characteristics of smoking and substance use behaviors

\begin{tabular}{ll}
\hline Characteristics & $\boldsymbol{n}$ \\
\hline Smoking & \\
$\quad$ No & \\
Ever & \\
Yes & \\
Length of smoking (Years) & \\
$\quad \leq 9$ \\
$\quad 10-19$
\end{tabular}

\section{$\%$}

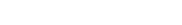

412

349

455

252

149

Amount of smoking (Cigarettes/day)

$$
\begin{aligned}
& \leq 10 \\
& 11-19 \\
& \geq 20 \\
& \text { Mean = 8, SD =6.78, Min =1, Max=50 }
\end{aligned}
$$

\section{Types of cigarette}

Traditional tobacco

Commercial cigarette

Electronic cigarette

\section{Smoking in family}

Yes

No

Source of cigarette buying

From their village

Outside of their village

Cost of cigarettes per day (Baht)

Less than 50 baht

More than 50 baht

Smoking in house (Indoor building)

Yes

No

Knowledge of the harms of smoking

Low

Moderate

Good

Attitudes toward the harms of smoking

Low

Moderate

Good

Alcohol use

Yes

No

Amphetamine use

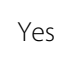

No
63.7

15.7

20.6

\section{1}

31.3

18.6

\section{1}

7.6
Table 2 Characteristics of smoking and substance use behaviors (Continued)

\begin{tabular}{lll}
\hline Characteristics & $\boldsymbol{n}$ & \% \\
\hline Opium use & & \\
Yes & 92 & 4.2 \\
No & 2124 & 95.8 \\
Marijuana use & & \\
Yes & 59 & 2.7 \\
No & 2157 & 97.3 \\
\hline
\end{tabular}

have reported different prevalence rates of smoking: $54.0 \%$ in China [28], 67.8\% in Japan [29], and 22.8\% in Malaysia [30]. In the data analysis of different tobacco control interventions in Thailand [31], the prevalence was $29.2 \%$ in Thailand, slightly greater than the prevalence among the hill tribe people. Gautami et al. [32] reported that the prevalence of smoking among the female Thai population aged 15 years and older was 3.4\%, and people living in rural northern regions reported the highest prevalence, which was lower than that of hill tribe women.

Interestingly, pulmonary function was not significantly different among those who currently smoked, ever smoked, and never smoked. A study conducted in the United States reported that former smokers and current smokers had a significantly poorer lung function than never smokers [33]. A study in Pakistani youths in 2018 reported that smoking behaviors were associated with

\begin{tabular}{|c|c|c|c|c|c|c|c|c|}
\hline \multirow[t]{3}{*}{ Characteristics } & \multicolumn{6}{|c|}{ Smoking behavior } & \multirow[t]{3}{*}{$x^{2}$} & \multirow[t]{3}{*}{$p$-value } \\
\hline & \multicolumn{2}{|l|}{ Yes } & \multicolumn{2}{|c|}{ Ever } & \multicolumn{2}{|l|}{ No } & & \\
\hline & $n$ & $\%$ & $n$ & $\%$ & $n$ & $\%$ & & \\
\hline \multicolumn{9}{|l|}{ Sex } \\
\hline Male & 370 & 36.7 & 284 & 28.2 & 353 & 35.1 & 655.97 & $<0.001^{*}$ \\
\hline Female & 85 & 7.0 & 65 & 5.4 & 1059 & 87.6 & & \\
\hline \multicolumn{9}{|l|}{$\mathrm{FEV}_{1}(\%)$} \\
\hline Normal $(\geq 80)$ & 262 & 22.6 & 207 & 17.9 & 689 & 59.5 & 0.24 & 0.884 \\
\hline Low $(<80)$ & 136 & 23.7 & 101 & 17.6 & 337 & 58.7 & & \\
\hline \multicolumn{9}{|l|}{ FVC (\%) } \\
\hline Normal $(\geq 80)$ & 187 & 23.7 & 130 & 16.5 & 473 & 59.9 & 1.84 & 0.398 \\
\hline Low $(<80)$ & 211 & 22.4 & 178 & 18.9 & 553 & 58.7 & & \\
\hline \multicolumn{9}{|l|}{ FEV/FVC } \\
\hline Normal $(\geq 0.8)$ & 397 & 23.1 & 305 & 17.7 & 1017 & 59.2 & 1.74 & $0.460^{\mathrm{a}}$ \\
\hline Low $(<0.8)$ & 1 & 7.7 & 3 & 23.1 & 9 & 69.2 & & \\
\hline \multicolumn{9}{|c|}{ Oxygen saturation (\%) } \\
\hline Normal (94-100) & 443 & 20.4 & 339 & 15.6 & 1388 & 64.0 & 2.75 & 0.252 \\
\hline Lower (<94) & 12 & 26.1 & 10 & 21.7 & 24 & 52.2 & & \\
\hline
\end{tabular}
declining pulmonary function [34]. In Thailand, a

Table 3 Comparison of the spirometry outcomes by sex among people with smoking experience 
Table 4 Univariate and multivariate analyses to identify factors associated with current smoking

\begin{tabular}{|c|c|c|c|c|c|c|c|c|c|c|}
\hline \multirow[t]{3}{*}{ Characteristics } & \multicolumn{4}{|c|}{ Current smoking } & \multirow[t]{3}{*}{ OR } & \multirow[t]{3}{*}{$95 \% \mathrm{Cl}$} & \multirow[t]{3}{*}{$p$-value } & \multirow[t]{3}{*}{ AOR } & \multirow[t]{3}{*}{$95 \% \mathrm{Cl}$} & \multirow[t]{3}{*}{$p$-value } \\
\hline & \multicolumn{2}{|l|}{ Yes } & \multicolumn{2}{|l|}{ No } & & & & & & \\
\hline & $n$ & $\%$ & $n$ & $\%$ & & & & & & \\
\hline \multicolumn{11}{|l|}{ Sex } \\
\hline Male & 370 & 36.7 & 637 & 63.3 & 7.68 & $5.95-9.91$ & $<0.001^{*}$ & 7.52 & $5.53-10.24$ & $<0.001^{*}$ \\
\hline Female & 85 & 7.0 & 1124 & 93.0 & 1.00 & & & 1.00 & & \\
\hline \multicolumn{11}{|l|}{ Age (years) } \\
\hline $20-29$ & 14 & 34.1 & 27 & 65.9 & 1.99 & $1.00-3.98$ & $0.049^{*}$ & & & \\
\hline $30-39$ & 78 & 17.0 & 380 & 83.0 & 0.79 & $0.56-1.11$ & 0.182 & & & \\
\hline $40-49$ & 148 & 20.6 & 569 & 79.4 & 1.00 & $0.74-1.35$ & 0.988 & & & \\
\hline $50-59$ & 133 & 22.1 & 469 & 77.9 & 1.09 & $0.80-1.49$ & 0.575 & & & \\
\hline$\geq 60$ & 82 & 20.6 & 316 & 79.4 & 1.00 & & & & & \\
\hline \multicolumn{11}{|l|}{ Tribe } \\
\hline Akha & 95 & 22.6 & 326 & 77.4 & 1.00 & & & & & \\
\hline Lahu & 89 & 23.0 & 298 & 77.0 & 1.02 & $0.73-1.42$ & 0.884 & & & \\
\hline Hmong & 23 & 6.3 & 341 & 93.7 & 0.23 & $0.14-0.37$ & $<0.001^{*}$ & & & \\
\hline Yao & 92 & 26.6 & 254 & 73.4 & 1.24 & $0.89-1.72$ & 0.197 & & & \\
\hline Karen & 90 & 27.4 & 239 & 72.6 & 1.29 & $0.92-1.80$ & 0.131 & & & \\
\hline Lishu & 66 & 17.9 & 303 & 82.1 & 0.74 & $0.52-1.06$ & 0.104 & & & \\
\hline \multicolumn{11}{|l|}{ Marital status } \\
\hline Single & 43 & 34.1 & 83 & 65.9 & 1.00 & & & & & \\
\hline Married & 378 & 19.8 & 1530 & 80.2 & 0.47 & $0.32-0.70$ & $<0.001^{*}$ & & & \\
\hline Widowed & 19 & 17.1 & 92 & 82.9 & 0.39 & $0.21-0.73$ & $0.003^{*}$ & & & \\
\hline Divorce & 15 & 21.1 & 56 & 78.9 & 0.51 & $0.26-1.01$ & 0.057 & & & \\
\hline \multicolumn{11}{|l|}{ Religion } \\
\hline Buddhist & 185 & 15.9 & 982 & 84.1 & 1.00 & & & & & \\
\hline Christian & 270 & 26.9 & 732 & 73.1 & 1.95 & $1.58-2.41$ & $<0.001^{*}$ & & & \\
\hline \multicolumn{11}{|l|}{ Education } \\
\hline Uneducated & 222 & 18.8 & 962 & 81.3 & 1.00 & & & & & \\
\hline Primary education & 155 & 27.1 & 417 & 72.9 & 1.60 & $1.27-2.03$ & $<0.001^{*}$ & & & \\
\hline Secondary education & 56 & 16.4 & 285 & 83.6 & 0.85 & $0.61-1.17$ & 0.327 & & & \\
\hline High Vocational Certificate & 11 & 13.3 & 72 & 86.7 & 0.66 & $0.34-1.26$ & 0.214 & & & \\
\hline Bachelor's degree or higher & 11 & 31.4 & 24 & 68.6 & 1.98 & $0.95-4.11$ & 0.065 & & & \\
\hline \multicolumn{11}{|l|}{ Annual family income (baht) } \\
\hline$\leq 10,000$ & 36 & 17.1 & 174 & 82.9 & 1.00 & & & & & \\
\hline $10,001-50,000$ & 306 & 23.2 & 1015 & 76.8 & 1.45 & $0.99-2.13$ & 0.053 & & & \\
\hline $50,001-100,000$ & 80 & 17.2 & 386 & 82.8 & 1.00 & $0.65-1.54$ & 0.994 & & & \\
\hline$\geq 100,001$ & 33 & 15.1 & 186 & 84.9 & 0.85 & $0.51-1.43$ & 0.559 & & & \\
\hline \multicolumn{11}{|l|}{ Occupation } \\
\hline Unemployed & 28 & 15.1 & 157 & 84.9 & 1.00 & & & & & \\
\hline Merchant & 5 & 9.4 & 48 & 90.6 & 0.58 & $0.21-1.60$ & 0.300 & & & \\
\hline Employee & 71 & 30.5 & 162 & 69.5 & 2.47 & $1.51-4.03$ & $<0.001^{*}$ & & & \\
\hline Agriculture & 351 & 20.1 & 1393 & 79.9 & 1.42 & $0.93-2.16$ & 0.099 & & & \\
\hline
\end{tabular}


Table 4 Univariate and multivariate analyses to identify factors associated with current smoking (Continued)

\begin{tabular}{|c|c|c|c|c|c|c|c|c|c|c|}
\hline \multirow[t]{3}{*}{ Characteristics } & \multicolumn{4}{|c|}{ Current smoking } & \multirow[t]{3}{*}{ OR } & \multirow[t]{3}{*}{$95 \% \mathrm{Cl}$} & \multirow[t]{3}{*}{$p$-value } & \multirow[t]{3}{*}{ AOR } & \multirow[t]{3}{*}{$95 \% \mathrm{Cl}$} & \multirow[t]{3}{*}{$p$-value } \\
\hline & \multicolumn{2}{|l|}{ Yes } & \multicolumn{2}{|l|}{ No } & & & & & & \\
\hline & $n$ & $\%$ & $n$ & $\%$ & & & & & & \\
\hline \multicolumn{11}{|l|}{ Alcohol use } \\
\hline Yes & 278 & 29.5 & 664 & 70.5 & 2.59 & $2.10-3.20$ & $<0.001^{*}$ & & & \\
\hline No & 177 & 13.9 & 1097 & 86.1 & 1.00 & & & & & \\
\hline \multicolumn{11}{|c|}{ Amphetamine use } \\
\hline Yes & 49 & 49.0 & 51 & 51.0 & 4.04 & $2.69-6.07$ & $<0.001^{*}$ & 2.92 & $1.69-5.03$ & $<0.001^{*}$ \\
\hline No & 406 & 19.2 & 1710 & 80.8 & 1.00 & & & 1.00 & & \\
\hline \multicolumn{11}{|l|}{ Opium use } \\
\hline Yes & 35 & 38.0 & 57 & 62.0 & 2.49 & $1.61-3.84$ & $<0.001^{*}$ & & & \\
\hline No & 420 & 19.8 & 1704 & 80.2 & 1.00 & & & & & \\
\hline \multicolumn{11}{|l|}{ Marijuana use } \\
\hline Yes & 25 & 42.4 & 34 & 57.6 & 2.95 & $1.74-5.00$ & $<0.001^{*}$ & & & \\
\hline No & 430 & 19.9 & 1727 & 80.1 & 1.00 & & & & & \\
\hline \multicolumn{11}{|c|}{ Knowledge of the harms of smoking } \\
\hline Low & 45 & 20.5 & 174 & 79.5 & 1.00 & $0.69-1.45$ & 0.984 & & & \\
\hline Moderate & 131 & 17.9 & 599 & 82.1 & 0.84 & $0.65-1.09$ & 0.849 & & & \\
\hline Good & 168 & 20.5 & 652 & 79.5 & 1.00 & & & & & \\
\hline \multicolumn{11}{|c|}{ Attitudes toward the harms of smoking } \\
\hline Low & 195 & 27.2 & 521 & 72.8 & 3.25 & $2.10-5.04$ & $<0.001^{*}$ & 2.47 & $1.53-3.97$ & $<0.001^{*}$ \\
\hline Moderate & 123 & 15.4 & 678 & 84.6 & 1.57 & $1.00-2.47$ & $0.047^{*}$ & 1.36 & $0.84-2.21$ & 0.203 \\
\hline Good & 26 & 10.3 & 226 & 89.7 & 1.00 & & & 1.00 & & \\
\hline \multicolumn{11}{|l|}{$\mathrm{FEV}_{1}(\%)$} \\
\hline Normal & 262 & 22.6 & 896 & 77.4 & 1.00 & & & & & \\
\hline Low & 136 & 23.7 & 438 & 76.3 & 1.06 & $0.83-1.34$ & 0.619 & & & \\
\hline \multicolumn{11}{|l|}{ FVC (\%) } \\
\hline Normal & 187 & 23.7 & 603 & 76.3 & 1.00 & & & & & \\
\hline Low & 211 & 22.4 & 731 & 77.6 & 0.93 & $0.74-1.16$ & 0.531 & & & \\
\hline \multicolumn{11}{|l|}{$\mathrm{FEV}_{1} / \mathrm{FVC}$} \\
\hline Normal & 397 & 23.1 & 1322 & 76.9 & 1.00 & & & & & \\
\hline Low & 1 & 7.7 & 12 & 92.3 & 0.21 & $0.36-2.14$ & 0.219 & & & \\
\hline \multicolumn{11}{|c|}{ Oxygen saturation (\%) } \\
\hline Normal & 443 & 20.4 & 1727 & 79.6 & 1.00 & & & & & \\
\hline Low & 12 & 26.1 & 34 & 73.9 & 1.37 & $0.70-2.67$ & 0.348 & & & \\
\hline
\end{tabular}

*Significant difference at $\alpha=0.05$, after adjusting for potential confounders (sex, age, education, and religion)

community-based cross-sectional study reported that long-term smoking behaviors affected potential lung function [13]. To detect the association between smoking behaviors and lung function, a stronger study design, such as a case-control or a cohort study, is needed.

In this study, we found that men had a 7.52 times greater chance of being a current smoker than women among hill tribe people aged 20 years and older. This finding coincides with a study in Ethiopia [35] reporting that men had a significantly greater chance of being current smokers than women. The finding was also supported by a study in Japan, reporting that men were at a greater risk of being current smokers than women among Japanese adults [36]. Additionally, a multifactor study in Korea reported that men had a greater likelihood of current smoking than women [37]. Moreover, men living in northern Thailand had a statistically greater risk of current smoking than women [38]. A 
triple country study in 2019 reported that male sex was a strong factor associated with current smoking in the Thai population [39].

A study in the United States in 2017 reported that the use of some substances, such as amphetamines, led to cigarette use [40]. Chomchoei et al. [41] reported that smoking could lead to the initiation of amphetamine use, which could also lead to smoking in the Akha and Lahu adult populations in northern Thailand. A qualitative study in Thailand reported that cigarette use and amphetamine use were significant among the young Thai population [42].

Among the hill tribe adults aged 20 years and older, those with poor attitudes toward the harms of smoking had greater odds of current smoking than those with good attitudes toward the harms of smoking. This finding coincides with that in a study in China [43] reporting that those with a better attitude toward the harms of smoking had less opportunity to smoke and a greater chance to quit smoking than those with a poor attitude. Additionally, a study in Taiwan among military conscripts [44] found that those with a better attitude toward the harms of smoking were at a lower risk of current smoking than those with poor attitudes toward the harms of smoking. A study of nursing students in Italy [45] demonstrated that having a good attitude toward the harms of smoking was associated with a lower risk of current smoking than those with a poor attitude toward the harms of smoking. A cross-sectional study in Lebanon [46] also reported that having a good attitude toward the harms of smoking was protective against current smoking behaviors among university students. This finding was similar to that in a study among medical students in Argentina [47] reporting that having a good attitude toward the harms of smoking was a protective factor against current smoking behaviors. A study in Bangkok [48], central Thailand, reported that poor knowledge of the harmful effects of smoking was a risk factor for current smoking.

Some limitations were found during this study. First, the ability of some participants to completely understand the content of the study was limited because their knowledge of Thai was limited. However, the village health volunteers were asked to help explain some questions on the questionnaire before completion of the form. Second, during the collection of information on pulmonary function using spirometry, the participants needed to strictly follow the instructions to ensure that the correct results were obtained. However, elderly persons did not clearly understand or correctly follow the instructions. This issue was improved by explanations of the details of the instructions by local health volunteers who were fluent in Thai and their local languages.

\section{Conclusion}

The hill tribe people in northern Thailand live with a poor education and economic status. Moreover, hill tribe people aged 20 years and older face a high prevalence of smoking behaviors and the use of several substances. Most of them smoke traditional tobacco and easily obtain cigarettes in their villages. Smoking behaviors are dominant in men, those with a poor attitude on smoking harms, and among those who used amphetamine. The hill tribe people must improve their knowledge on the harms of smoking to improve their attitude eventually. This point is critical for reducing smoking behavior, particularly in the male population. However, to improve knowledge, public health professionals must simplify the method and tools for providing health education because more than half of the hill tribe people are not educated. Moreover, all health messages should be translated in the hill tribe languages to achieve ultimately successful communication.

\section{Supplementary information}

The online version contains supplementary material available at https://doi. org/10.1186/s12889-020-09857-1.

\section{Additional file 1. Questionnaire.}

\section{Abbreviations \\ ATS: American Thoracic Society; CA: Cancer; Cl: Confidence interval: COPD: Chronic obstructive pulmonary disease; CVDs: Cardiovascular diseases;

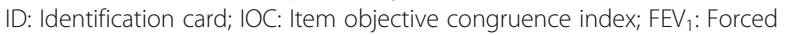 expiratory volume in the first second; FVC: Forced vital capacity; FEV 1 / FVC: Ratio of FEV 1 and FVC; $\mathrm{O}_{2}$ : Oxygen; SD: Standard deviation; WHO: World Health Organization}

\section{Acknowledgments}

We would like to thank the School of Nursing, Mae Fah Luang University and the village headmen for their valuable support during the study.

\section{Authors' contributions}

AM developed the research tools, collected the data, interpreted the analysis, and drafted and approved the manuscript. RT, PU, FY and TA collected the data, analyzed the data, wrote the manuscript, and approved the manuscript.

\section{Funding}

The study was supported by the Center of Excellence for Hill Tribe Health Research, Mae Fah Luang University and The National Research Council of Thailand (No. 22/2561). The funders had no role in the design of the study, collection, analysis, and interpretation of the data and writing of the manuscript.

\section{Availability of data and materials}

The raw data are available upon reasonable request from the corresponding author.

\section{Ethics approval and consent to participate}

The study concept and protocols were approved by the Chiang Rai Provincial Health Office Ethics Committee on Human Research (No. CRPPHO 16/2562), and all participants provided written informed consent before the interview voluntarily. However, those who did not understand the content written in Thai were provided explanations of all the content on the consent form by village health volunteers before fingerprinting into the informed consent form. 


\section{Consent for publication}

Not applicable.

\section{Competing interests}

The authors declare that they have no competing interests.

\section{Author details}

'Department of Physical Therapy, School of Integrative Medicine, Mae Fah Luang University, Chiang Rai, Thailand. ${ }^{2}$ Department of Public Health, School of Health Science, Mae Fah Luang University, Chiang Rai, Thailand. ${ }^{3}$ Center of Excellence for The Hill tribe Health Research, Mae Fah Luang University, Chiang Rai, Thailand.

\section{Received: 15 June 2020 Accepted: 9 November 2020} Published online: 16 November 2020

\section{References}

1. American Lung Association. Lung cancer fact sheet. 2019. Available from: https://www.lung.org/lung-health-diseases/lung-disease-lookup/lungcancer/resource-library/lung-cancer-fact-sheet.

2. Furrukh M. Tobacco smoking and lung cancer: perception-changing facts. Sultan Qaboos Univ Med J. 2013;13(3):345-8.

3. Messner B, Bernhard D. Smoking and cardiovascular disease: mechanisms of endothelial dysfunction and early atherogenesis. Arterioscler Thromb Vas Biol. 2014;34:509-15.

4. Global Initiative for Chronic Obstructive Lung Disease. Global strategy for the diagnosis, management, and prevention of chronic obstructive pulmonary disease 2019 report. Available from: https://goldcopd.org/wpcontent/uploads/2018/11/GOLD-2019-v1.7-FINAL-14Nov2018-WMS.pdf

5. Hall W, Doran C. How much can the USA reduce health care costs by reducing smoking? Plos Med. 2016;13(5):1-3. e10022021. https://doi.org/10. 1371/journal.pmen.1002021.

6. World Health Organization (WHO). Tobacco: fact sheet. 2020. Available from: https://www.who.int/news-room/fact-sheets/detail/tobacco.

7. World Health Organization (WHO). Implementing economic policies on tobacco control. 2019. Available from: https://www.who.int/activities/ implementing-economic-policies-on-tobacco-control.

8. The World Bank. Country economic profile: Thailand. 2019. Available from: https://www.worldbank.org/en/country/thailand/overview.

9. United Nations (UN). Thailand country profile. 2019. Available from: http:// www.un.or.th/wp-content/uploads/2018/05/UNCT-annual-report-finalprinted-version.pdf.

10. Thai Health promotion Foundation. Smoking and medical cost Thailand in 2017. 2018. Available from: https://www.thaihealth.or.th/.

11. National Statistical Thailand (NSO). Smoking situation in Thailand. 2018. Available from: http://www.nso.go.th/sites/2014/Pages/News/2561/N3108-61-1.aspx.

12. World Health organization (WHO). Thailand-global cancer observatory. 2019. Available from: https://gco.iarc.fr/today/data/factsheets/populations/764thailand-fact-sheets.pdf.

13. Sukchan P, Lim A, Rongpan S, Puboonpol G, Santiparadon M. Epidemiological survey of smoking and pulmonary function test among adult male smokers in poverty coastal finshing community. J Med Assoc Thail. 2020;103(3):262-9.

14. World Health Organization (WHO). Joint national capacity assessment on the implementation of effective tobacco control policies in Thailand. Available from: https://apps.who.int/iris/bitstream/handle/10665/44762/9789241502757_ eng.pdf;jsessionid=86B34CA69A9ED01CB3B77C68DFA1AAC2? sequence=1 ].

15. Princess Maha Chakri Siridhorn Anthropology center. Hill tribe. 2018. Available from: http://www.sac.or.th/main/index.php.

16. World Health Organization (WHO)-Thailand. Technical consultation to strengthen hypertension care in Thailand, 2017. 2017. Available from: http:// www.searo. who.int/thailand/news/htn-meeting-report-draft24nov.pdf?ua=1.

17. Singkorn O, Apidechkul T, Putsa B, Detpetukyon S, Sunsern R, Thutsanti P, et al. Factors associated with alcohol use among Lahu and Akha hill tribe youths, northern Thailand. Subst Abuse Treat Prevent Policy. 2019;19(5):114. https://doi.org/10.1186/s13011-0193-6.

18. Apidechkul T, Laingoen O, Suwannaporn S. Inequity in accessing health care service in Thailand in 2015: a case study of the hill tribe people in Mae Fah Luang District, Chiang Rai, Thailand. J Health Res. 2016;30(1):67-71 https://doi.org/10.14456/jhr.2016.10.
19. Department of Provincial Administration, Ministry of Interior. Act on the card 2011. Available from: http://www.moi.go.th/portal/page?_pageid=814 ,1036627,814_1036665\&_dad=portal\&_schema=PORTAL].

20. Charan H, Bisws T. How to calculate sample size for different study designs in medical research? Indain J Psychol Med. 2013;35(2):121-6.

21. Aungkulanon S, Pitayarangsarit S, Bundhamcharoen K, Akaleephan C, Chongsuvivatwong $\mathrm{V}$, Phoncharoen $\mathrm{R}$, et al. Smoking prevalence and attributable deaths in Thailand: predicting outcomes of different tobacco control interventions. BMC Public Health. 2019;19(984):1-11. https://doi.org/ 10.1186/s12889-019-7332-x.

22. Brian L. Graham, Irene Steenbruggen, Martin R. Miller, Igor Z. Barjaktarevic, Brendan G. Cooper, Graham L. Hall, et al. Standardization of Spirometry 2019 Update An Official American Thoracic Society and European Respiratory Society Technical Statement. Am J Respir Crit Care Med. 2019. 200:8.pp e70-88.

23. The hill tribe welfare and development center, Chiang Rai province. Hill tribe population. The hill tribe welfare and development center. Chiang Rai: Ministry of Interior; 2018. p. 16-26.

24. Ministry of Education, Thailand. Average of years in school of Thai population in 2018. Available from: http://backoffice.onec.go.th/uploads/ Book/1554-file.pdf.

25. National Statistic Office. The 2019 household socio-economic survey: whole kingdom. Available from: http://www.nso.go.th/sites/2014en/Lists/ NewPublications/Attachments/161/THE_2019_\%20HSEs.pdf.

26. Pinkas J, Kaleta D, Zgliczynski WS, Lusawa A, Wrzesniewska-Wal I, Wierzba W et al. The prevalence of tobacco and e-cigarette use in Poland: a 2019 nationwide cross-sectional survey. Int J Environ Res Public Health. 2019; 16(23):1-12. https://doi.org/10.3390/ijerph16234820.

27. Brozek GM, Jankowski M, Lawson JA, Shpakou A, Poznanski M, Zielonka TM, et al. The prevalence of cigarette and e-cigarette smoking among students in central and eastern Europe-results of the YUPESS study. Int Environ Res Public Health. 2019;16(13):1-14. https://doi.org/10.3390/ijerph16132297.

28. Liu S, Zhang M, Yang L, Li Y, Wang L, Huang Z, et al. Prevalence and patterns of tobacco smoking among Chinese adult men and women: findings of the 2010 national smoking survey. BMJ J Epidemiol Commun Health. 2017;71:154-61.

29. Sutanto E, Miller C, Smith DM, O'Connor RJ, Quah AC, Cummings KM, et al. Prevalence, use behaviors, and preference among users of heated tobacco products: findings from the 2018 ITC Japan survey. Int J Environ Res Public Health. 2019;16(23):1-18. https://doi.org/10.3390/ijerph16234630.

30. Lim KH, The $\mathrm{CH}$, Pan S, Ling MY, Yusoff MF, Ghazali SM, et al. Prevalence and factors associated with smoking among adults in Malaysia-findings from the national health and morbidity survey (NHMS) 2015. Tobacco Induced Dis. 2018;16(1):12. https://doi.org/10.18332/tid/82190.

31. World Health Organization (WHO). Factsheet Thailand: 2018. Available from: https://apps.who.int/iris/bitstream/handle/10665/272690/wntd_2018_ thailand_fs.pdf?sequence $=1$.

32. Gautami N, Lim A, Ueranantasun A. Demographic and regional trends of smoking among Thai females from 1986 to 2014. Epidemiol Biostat Public Health. 2019;16(3):e13072.

33. Oelsner EC, Balte PP, Bhatt SP, Cassano PA, Couper D, Folsom AR, et al. Lung function decline in former smokers and low-ontensity current smokers: a cross-sectional data analysis of the NHLBI pooled cohort study. Lancet Respir Med. 2020;8(1):34-44.

34. Mehmood M, Shahid MA, Saleem A. Analysis of effects of smoking on lung function, and respiratory muscle strength of Pakistani youth. Biomed J Sci Technical Res. 2018;7(5):6158-60.

35. Eticha T, Kidane F. The prevalence of and factors associated with current smoking among college of health sciences students, Mekelle University in northern Ethiopia. Plos One. 2014;9(10): 1-6. e111033.

36. Tamaki T, Kaneita Y, Ohida T, Yokoyama E, Osaki Y, Kanda H, et al. Prevalence of and factors associated with smoking among Japanese medical students. J Epidemiol. 20101;20(4):339-45.

37. Kim EM, Park E, Kim H. Sex difference in multilevel factors of smoking experimentation and age of initiation in Korean adolescents. J Sch Nurs. 2019;26(5):348-59. https://doi.org/10.1177/1059840519840805.

38. Chaikoolvatana C, Sutti P, Jaimalai W. Smoking behaviors and risk factors associated with smoking of elderly adolescents in Pha Yao Province, Thailand. Nurs J Ministry Public Health. 2017;27(3):57-67.

39. Joung $\mathrm{KH}$, Chung SS. Factors affecting cigarette smoking among adolescents in south Korea, Vietnam, and Thailand. J Special Pediatric Nurs. 2019;24(4). https://doi.org/10.1111/jspn.12267. 
40. Cross SJ, Lotfipour S, Leslie FM. Mechanisms and genetic factors underlying co-use of nicotine and alcohol or other drugs of abuse. Am J Drug Alcohol Abuse. 2017;43(2):171-85.

41. Chomchoei C, Apidechkul T, Wongnuch P, Tamornpark R, Upala P, Nongkhai MP. Perceived factors influencing the initiation of methamphetamine use among Akha and Lahu youths: a qualitative approach. BMC Public Health. 2019;19(847):1-11. https://doi.org/10.1186/ s12889-019-7226-y.

42. Sherman S, German D, Siriroj B, Celentano DD. Initiation of methamphetamine use among young Thai drug users: a qualitative study. J Adolesc Health. 2008:42(1):36-42.

43. Xu X, Liu L, Sharma M, Zhao Y. Smoking-related knowledge, attitudes, behaviors, smoking cessation idea and education level among young adult male smokers in Chongqing, China. Int J Environ Res Public Health. 2015;12: 2135-9.

44. Lin YS, Wu DM, Lai HR, Shi ZP, Chu NF. Influence of knowledge and attitudes in smoking habits among young military conscripts in Taiwan. J Chin Med Assoc. 2010;73(8):411-8.

45. Provenzano S, Santangelo OE, Grigis D, Giordano D, Firenze A. Smoking behavior among nursing students: attitudes towards smoking cessation. J Prev Med Hyg. 2019;60(3):E203-10.

46. Chaaya M, Alameddine M, Nakkash R, Afifi RA, Khali J, Nahhas G. Students' attitude and smoking behavior following the implementation of a university smoke-free policy: a cross-sectional study. BMJ Open. 2013; 3(4):1-8. e002100.

47. Salgado MV, Mejia RM, Kaplan CP, Perez-Stable EJ. Smoking-related attitudes and knowledge among medical students and recent graduated in Argentina: a cross-sectional study. J Gen Intern Med. 2017;32:549-55.

48. Thamkhantho M. Knowledge about and attitude towards harms of cigarette smoking among pregnant women attending the out-patients antenatal care clinic at Siriraj hospital. J Med Assoc Thail. 2018;101(1):13-8.

\section{Publisher's Note}

Springer Nature remains neutral with regard to jurisdictional claims in published maps and institutional affiliations.

Ready to submit your research? Choose BMC and benefit from:

- fast, convenient online submission

- thorough peer review by experienced researchers in your field

- rapid publication on acceptance

- support for research data, including large and complex data types

- gold Open Access which fosters wider collaboration and increased citations

- maximum visibility for your research: over $100 \mathrm{M}$ website views per year

At $\mathrm{BMC}$, research is always in progress.

Learn more biomedcentral.com/submissions 